\title{
PEMANFAATAN BIOCHAR DAN LIMBAH IKAN TERHADAP PERTUMBUHAN DAN PRODUKSI TANAMAN JAGUNG MANIS (Zea mays saccharata $\mathrm{L}$ )
}

\author{
Rosmaiti $^{1}$, Murdhiani ${ }^{1}$, Pariyem ${ }^{2}$ \\ ${ }^{1}$ Dosen Program Studi Agroteknologi, Fakultas Pertanian Universitas Samudra \\ ${ }^{2}$ Alumni Program Studi Agroteknologi, Fakultas Pertanian Universitas Samudra \\ e-mail: rosmaitimp@gmail.com
}

\begin{abstract}
ABSTRAK
Tujuan penelitian untuk mengetahui pertumbuhan dan produksi tanaman jagung manis terhadap biochar dan limbah ikan serta interaksi antara kedua perlakuan tersebut. Penelitian ini menggunakan Rancangan Acak Kelompok (RAK) pola faktorial, yang terdiridari 2 faktor, yaitu faktor Biochar dan faktor limbah ikan. Parameter yang diamati yaitu: tinggi tanaman, jumlah daun, diameter batang, panjang tongkol, bobot tongkol tanaman sampel dan produksi per plot. Hasil penelitian menunjukkan perlakuan Biochar berpengaruh sangat nyata terhadap tinggi tanaman pada umur 30 dan 45 HST, jumlah daun 30 dan 45 HST, panjang tongkol, bobot tongkol tanaman sampel serta produksi per plot. Perlakuan terbaik didapatkan pada perlakuan $\mathrm{B}_{4}$ (biochar 7,5 ton/ha). Perlakuan limbah ikan berpengaruh sangat nyata terhadap tinggi tanaman pada umur 30 dan 45 HST, jumlah daun 30 dan 45 HST, panjang tongkol, bobot tongkol tanaman sampel serta produksi per plot. Perlakuan terbaik didapatkan pada perlakuan $\mathrm{L}_{4}$ (limbah ikan $150 \mathrm{ml} /$ liter air). Interaksi antara biochar dan limbah ikan berpengaruh sangat nyata terhadap tinggi tanaman dan jumlah daun umur 15, 30 dan 45 HST, diameter batang, panjang tongkol, bobot tanaman sampel serta produksi per plot. Interaksi terbaik dijumpai pada kombinasi perlakuan biochar 7,5 ton/ha dan limbah ikan $150 \mathrm{ml} / \mathrm{liter}$ air $\left(\mathrm{B}_{4} \mathrm{~L}_{4}\right)$. Untuk mendapatkan pertumbuhan dan produksi tanaman jagung manis yang baik disarankan melakukan budidaya jagung manis dengan biochar (7,5 ton/ha) yang dikombinasikan dengan limbah ikan (150 $\mathrm{ml} /$ liter air).
\end{abstract}

Kata kunci : Jagung manis, biochar, limbah ikan. 


\section{PENDAHULUAN}

Jagung manis (Zea mays saccharata L) merupakan salah satu tanaman pangan Indonesia yang digunakan untuk bahan makanan pokok setelah padi dan gandum. Selain sebagai sumber karbohidrat, bijinya dapat dibuat menjadi minyak atau dibuat menjadi tepung atau meizena dan tongkolnya dapat menjadi bahan baku industri.Jagung yang sudah direkayasa genetiknya sekarang ditanam sebagai penghasil bahan fermentasi (Prahasta, 2009).

Kebutuhan jagung manis untuk konsumsi terus meningkat terutama didaerah perkotaan dan yang mendukung pariwisata. Dibeberapa pasar lokal, permintaan terhadap jagungmanis terus meningkat mencapai 1-1,5 ton/hari. Permintaan pasar jagung manis juga disebabkan adanya perbaikan kadar gula dari varietas-varietas jagung manis (Syukur dan Azis, 2014).

Dalam tekhnik budidaya yang dapat dilakukan untuk meningkatkan produksi yaitu dengan perbaikan teknik budidaya seperti pemberian biochar dan penggunaan limbah ikan, kedua faktor tersebut salah satu cara yang dapat dilakukan untuk dapat meningkatkan produksi jagung manis. Biochar merupakan arang yang diberikan ke sistem tanah dan tanaman sebagai bahan pembenah tanah. Biochar dapat diproduksi dari berbagai bahan seperti kayu, sisa tanaman (jerami padi, sekam padi, tandan kosong kelapa sawit dan limbah sagu) dan pupuk kandang (Maguire dan Aglevor, 2010).

Menurut Dariah dan Nurida (2012), pemberian biochar sekam padi memberikan pengaruh nyata terhadap produksi tongkol basah tanaman jagung dibandingkan tanpa biochar dan meningkatkan produksi pipilan kering tanaman jagung lebih tinggi dibandingkan tanpa biochar.

Sebagai bahan pembenah tanah biochar banyak digunakan untuk mengatasi permasalahan pada tanah. Aplikasi biochar dapat meningkatkan $\mathrm{pH}$ pada tanah masam, meningkatkan KTK tanah, menyediakan unsur hara $\mathrm{N}, \mathrm{P}$ dan $\mathrm{K}$. Biochar menjaga kelembaban tanah sehingga kapasitas menahan air tinggi dan meremediasi tanah yang tercemar logam berat seperti $(\mathrm{Pb}, \mathrm{Cu}$, $\mathrm{Cd}$ dan Ni). Selain itu pemberian biochar pada tanah juga mampu meningkatkan pertumbuhan serta serapan hara pada tanaman (Satriawan dan Handyanto, 2015).

Limbah air ikan merupakan cairan yang berasal dari proses pemotongan, pencucian, dan pengolahan produk ikan yang tidak mempunyai nilai ekonomi. Limbah cair industri perikanan mengandung banyak protein dan lemak. Penggunaan pupuk organik cair pada tanaman dinilai dapat cepat untuk mengatasi kekurangan unsur hara dan mampu menyediakan hara secara cepat untuk membantu produktivitas tanaman (Hadisuwito, 2007).

Hasil penelitian Mursalim (2018), pupuk organik dari limbah ikan tongkol memberikan pengaruh nyata terhadap pertumbuhan tanaman sawi dengan dosis terbaik $100 \mathrm{ml} / \mathrm{L}$ air (10\%) karena diketahui bahwa dari kandungan protein ikan tongkol sebesar 36,10\% setara nitrogen sebesar 5,78\%.

Penelitian ini bertujuan untuk mengetahui pemanfaatan biochar dan limbah ikan terhadap pertumbuhan dan produksi tanaman jagung manis (Zea mays saccharata $\mathrm{L}$ ). 


\section{METODE PENELITIAN}

Waktu dan Tempat Penelitian

Penelitian ini dilaksanakan di

Desa Suka Rakyat Pondok Kemuning Kecamatan Langsa Lama, Kota Langsa dengan ketinggian tempat $\pm 10 \mathrm{~m}$ dpl (BPS Kota Langsa 2018) dan $\mathrm{pH}$ tanah 6,8. Pelaksanaan penelitian mulai dari bulan Desember 2018 sampai dengan Juni 2019.

\section{Bahan dan Alat}

Bahan-bahan yang digunakan dalam penelitian ini meliputi: benih jagung varietas ZM 866 Produksi PT Benih Citra Asia (BCA) Indonesia. Pupuk urea, SP36 dan KCL, decis 2,5 EC, limbah ikan, sekam padi, babybag, EM-4, gula merah dan bahan-bahan lainnya seperti paku, jaring, tali plastik, papan nama, papan perlakuan, serta papan plot.

Alat-alat yang digunakan terdiri dari: cangkul, garu, parang, meteran, penggaris, handsprayer, ember, pengaduk kayu, gembor, gelas ukur, karung, jangka sorong, timbangan, kalkulator, alat tulis dan alat dokumentasi.

\section{Metode Penelitian}

Penelitian ini menggunakan Rancangan Acak Kelompok (RAK) pola faktorial yang terdiri dari dua

Tabel 1. Rata-rata tinggi tanaman jagung manis $(\mathrm{cm})$ umur 15, 30 dan 45 HST akibat perlakuan Biochar

\begin{tabular}{cccc}
\multicolumn{4}{c}{ perlakuan Biochar } \\
\cline { 2 - 4 } Perlakuan & \multicolumn{4}{c}{ Tinggi Tanaman $(\mathrm{cm})$} \\
\cline { 2 - 4 } & $15 \mathrm{HST}$ & $30 \mathrm{HST}$ & $45 \mathrm{HST}$ \\
\hline $\mathrm{B}_{1}$ & 47,28 & $78.04 \mathrm{a}$ & $85,86 \mathrm{a}$ \\
$\mathrm{B}_{2}$ & 44,00 & $92,69 \mathrm{~b}$ & $150,36 \mathrm{~b}$ \\
$\mathrm{~B}_{3}$ & 54,31 & $153,69 \mathrm{c}$ & $218,56 \mathrm{c}$ \\
$\mathrm{B}_{4}$ & 52,08 & $179,56 \mathrm{~d}$ & $237,11 \mathrm{~d}$ \\
\hline BNJ $_{0,05}$ & - & 4,95 & 6,49 \\
\hline \multicolumn{2}{l}{ Keterangan : Angka yang diikuti huruf yang berbeda pada kolom yang sama berbeda } \\
nyata pada taraf 0,05
\end{tabular}

Keterangan : Angka yang diikuti huruf yang berbeda pada kolom yang sama berbeda nyata pada taraf 0,05 faktor, yaitu: Faktor I Biochar (B) terdiri dari 4 taraf yaitu: $\mathrm{B}_{1}=$ Tanpa biochar (kontrol), $\mathrm{B}_{2}=$ Biochar 2,5 ton $/$ ha $=(281,25 \mathrm{~g} / \mathrm{plot})$; $\mathrm{B}_{3}=$ Biochar 5 ton $/$ ha $=(562,5$ $\mathrm{g} /$ plot); $\mathrm{B}_{4}=$ Biochar 7,5 ton /ha $=(843,75 \mathrm{~g} /$ plot $)$. Faktor II Limbah ikan (L) terdiri dari 4 taraf yaitu: $\mathrm{L}_{1}=$ $0 \mathrm{ml}=$ (kontrol); $\mathrm{L}_{2}=50 \mathrm{ml}=$ (50 ml limbah ikan + 1 Liter air); $\mathrm{L}_{3}$ $=100 \mathrm{ml}=(100 \mathrm{ml}$ limbah ikan +1 Liter air $)$ dan $\mathrm{L}_{4}=150 \mathrm{ml}=(150 \mathrm{ml}$ limbah ikan +1 Liter air). Model matematika yang digunakan dalam penelitian ini (Hanafiah, 2014):

$\mathbf{Y}_{\mathrm{IJK}}=\mu+\boldsymbol{\beta}_{\mathrm{i}}+\mathbf{B}_{\mathrm{j}}+\mathbf{L}_{\mathrm{k}}+(\mathbf{B L})_{\mathrm{jk}}+E_{\mathrm{ijk}}$.

Parameter yang diamati meliputi: tinggi tanaman $(\mathrm{cm})$, bobot tongkol tanaman sampel (g), dan produksi per plot $(\mathrm{Kg})$.

\section{HASIL DAN PEMBAHASAN Pengaruh Biochar}

\section{Tinggi Tanaman $(\mathrm{cm})$}

Analisis sidik ragam menunjukkan bahwa perlakuan biochar berpengaruh sangat nyata terhadap tinggi tanaman pada umur 30 dan 45 HST akan tetapi berpengaruh tidak nyata pada umur 15 HST. Rata-rata tinggi tanaman jagung manis akibat perlakuan biochar pada umur 15, 30 dan 45 HST disajikan pada Tabel 1. 
Tabel 1 menunjukan bahwa pada umur 30 dan 45 HST perlakuan tertinggi dijumpai pada perlakuan $\mathrm{B}_{4}$ (biochar 7,5 ton/ha) dan terendah dijumpai pada perlakuan $\mathrm{B}_{1}$ (tanpa biochar). Hasil uji $\mathrm{BNJ}_{0,05}$ Pada umur 30 dan 45 HST Perlakuan $\mathrm{B}_{4}$ berbeda nyata dengan semua perlakuan yang lain.

Hal ini diduga biochar sekam padi sebagai salah satu bahan organik yang dapat memperbaiki sifat kimia, fisika dan biologi tanah. Biochar sekam padi lebih poros karena memiliki pori-pori makro dan mikro yang seimbang, sehingga sirkulasi udara yang dihasilkan cukup baik serta memiliki daya serap air yang tinggi. Kondisi ini akan berdampak positif terhadap pertumbuhan dan perkembangan tanaman jagung manis, dimana perakaran akan berkembang dengan baik sehingga pengambilan hara oleh akar akan optimal.

Menurut Hanafiah (2013), partikel-partikel bahan organik merupakan penyusun ruang pori yang berfungsi sebagai sumber air dan udara, serta sebagai ruang untuk akar berkembang, semakin banyak ruang pori akan dapat memperluas sistem perakaran dan perakaran dapat lebih mudah menyerap hara dan air dalam tanah.

Selain itu sekam bakar sebagai salah satu bahan organik akan mengalami proses pelapukan atau dekomposisi yang dilakukan oleh mikroorganisme. Melalui proses tersebut, akan dihasilkan karbondioksida, air dan mineral. Mineral yang dihasilkan merupakan sumber unsur hara yang dapat diserap tanaman sebagai zat makanan sehingga pertumbuhan tanaman menjadi maksimal.

\section{Bobot Tongkol Tanaman Sampel} (g)

Analisis sidik ragam menunjukan bahwa perlakuan biocharberpengaruh sangat nyata terhadap bobot tanaman sampel. Rata-rata bobot tanaman sampel jagung manis akibat perlakuan biochar disajikan pada Tabel 2 .

Tabel 2. Rata-rata bobot tanaman sampel jagung manis (g) akibat perlakuan biochar

\begin{tabular}{cc}
\hline Perlakuan & Bobot Tongkol Tanaman Sampel $(\mathrm{g})$ \\
\hline $\mathrm{B}_{1}$ & $203,58 \mathrm{a}$ \\
$\mathrm{B}_{2}$ & $291,58 \mathrm{~b}$ \\
$\mathrm{~B}_{3}$ & $419,08 \mathrm{c}$ \\
$\mathrm{B}_{4}$ & $278,19 \mathrm{ab}$ \\
\hline $\mathrm{BNJ}_{0,05}$ & 79,90 \\
\hline
\end{tabular}

Keterangan : Angka yang diikuti huruf yang berbeda, berbeda nyata pada taraf 0,05

Tabel 2 menunjukan bahwa bobot tanaman sampel jagung manis tertinggi dijumpai pada perlakuan $\mathrm{B}_{3}$ dan terendah dijumpai pada perlakuan $\mathrm{B}_{1}$. Hasil uji $\mathrm{BNJ}_{0,05}$ perlakuan $\mathrm{B}_{3}$ berbeda nyata dengan semua perlakuan yang lain. Diduga biochar sekam padi mampu memperbaiki sifat kimia, fisika dan biologi tanah sehingga meningkatkan kandungan $\mathrm{pH}$ tanah menjadi 6-7, sehingga proses absorpsi hara menjadi optimal, yang menyebabkan terbentuknya buah menjadi lebih sempurna.

Sesuai dengan pendapat Ogawa (1994) dalam Komarayati, dkk (2012) Biochar sekam padi 
diketahui sebagai pembenah tanah karena memiliki pori-pori yang dapat menyerap, dan menyimpan air dan hara. Biochar sekam padi juga dapat meningkatkan $\mathrm{pH}$ dan KTK tanah sehingga tanaman diberikan biochar sekam padi akan baik pertumbuhannya dan produksinya juga meningkat.
Produksi per Plot (kg)

Analisis sidik ragam menunjukan bahwa perlakuan biocharberpengaruh sangat nyata terhadapn produksi per plot. Ratarata produksi per plot jagung manis akibat perlakuan biochar disajikan pada Tabel 3.

Tabel 3. Rata-rata produksi per plot jagung manis $(\mathrm{kg})$ akibat perlakuan biochar

\begin{tabular}{cc}
\hline Perlakuan & Produksi per Plot $(\mathrm{kg})$ \\
\hline $\mathrm{B}_{1}$ & $1,11 \mathrm{a}$ \\
$\mathrm{B}_{2}$ & $2,41 \mathrm{~b}$ \\
$\mathrm{~B}_{3}$ & $3,77 \mathrm{~d}$ \\
$\mathrm{~B}_{4}$ & $3,07 \mathrm{c}$ \\
\hline $\mathrm{BNJ}_{0,05}$ & 0,31 \\
\hline
\end{tabular}

Keterangan: Angka yang diikuti huruf yang berbeda, berbeda nyata pada taraf 0,05

Tabel 3 menunjukan bahwa produksi per plot tanaman jagung manis tertinggi dijumpai pada perlakuan $\mathrm{B}_{3}$ dan terendah dijumpai pada perlakuan $\mathrm{B}_{1}$. Hasil uji $\mathrm{BNJ}_{0,05}$ perlakuan $\mathrm{B}_{3}$ berbeda nyata dengan semua perlakuan yang lain.

Hal ini diduga biochar sekam padi mampu memperbaiki kesuburan tanah dengan meningkatkan permeabilitas, porositas, struktur tanah, daya ikat air dan KTK tanah, sehingga mempertahankan unsur hara agar diserap oleh oleh akar tanaman sehingga kebutuhan hara terpenuhi dan menghasilkan produksi yang baik. Warnock, dkk (2007) menyatakan biochar sekam padi mampu menyerap unsur hara dan air

\section{Pengaruh Limbah Ikan}

\section{Tinggi Tanaman (cm)}

Analisis sidik ragam menunjukan bahwa perlakuan limbah ikan berpengaruh sangat nyata sehingga unsur hara dapat tersedia bagi tanaman. Selain itu biochar sekam padi mampu memperbaiki dan mengoptimalkan pertumbuhan serta produksi tanaman dan mengurangi jumlah nutrisi yang diserap tanaman hilang akibat tercuci.

Gani (2009) menambahkan bahwa pemberian biochar sekam padi dapat menahan dan menyebabkan nutrisi tersedia untuk tanaman. Jika sifat fisik tanah makin baik, maka pertumbuhan dan perkembangan tanaman juga makin baik. Apabila akar mudah menembus tanah, pertumbuhan tanaman secara keseluruhan akan makin cepat dan memberikan hasil yang tinggi.

terhadap tinggi tanaman pada umur 30 dan 45 HST akan tetapi berpengaruh tidak nyata pada umur 15 HST. Rata-rata tinggi tanaman jagung manis akibat perlakuan limbah ikan pada umur 15, 30 dan 45 HST disajikan pada Tabel 4. 
Tabel 4. Rata-rata tinggi tanaman jagung manis (cm) umur 15, 30 dan 45 HST akibat perlakuan limbah ikan

\begin{tabular}{cccc}
\hline \multirow{2}{*}{ Perlakuan } & \multicolumn{3}{c}{ Tinggi Tanaman $(\mathrm{cm})$} \\
\cline { 2 - 4 } & $15 \mathrm{HST}$ & $30 \mathrm{HST}$ & $45 \mathrm{HST}$ \\
\hline $\mathrm{L}_{1}$ & 46,67 & $86,42 \mathrm{a}$ & $96,22 \mathrm{a}$ \\
$\mathrm{L}_{2}$ & 50,25 & $97,03 \mathrm{~b}$ & $175,28 \mathrm{~b}$ \\
$\mathrm{~L}_{3}$ & 51,56 & $153,28 \mathrm{c}$ & $203,28 \mathrm{c}$ \\
$\mathrm{L}_{4}$ & 49,19 & $167,26 \mathrm{~d}$ & $209,81 \mathrm{~d}$ \\
\hline BNJ $_{0,05}$ & - & 4,95 & 6,49 \\
\hline
\end{tabular}

Keterangan : Angka yang diikuti huruf yang berbeda pada kolom yang sama berbeda nyata pada taraf 0,05

Tabel 4 menunjukan bahwa pada umur 30 dan 45 HST perlakuan tertinggi dijumpai pada perlakuan $\mathrm{L}_{4}$ (limbah ikan $150 \mathrm{ml} / \mathrm{liter}$ air) dan terendah dijumpai pada perlakuan $\mathrm{L}_{1}$ (tanpa limbah ikan). Hasil uji $\mathrm{BNJ}_{0,05}$ pada umur 30 dan 45 HST, perlakuan $\mathrm{L}_{4}$ berbeda nyata dengan semua perlakuan yang lain.

Hal ini diduga bahwa konsentrasi limbah ikan yang mengandung unsur hara $\mathrm{N} 1,65 \%, \mathrm{P}$ $0,18 \%$, K $0,27 \%$ yang diberikan sesuai dengan kebutuhan tanaman, sehingga dapat meningkatkan kesuburan tanah sehingga pertumbuhan tanaman menjadi lebih cepat. Menurut Prasetya (2009) kandungan unsur hara $\mathrm{N}, \mathrm{P}$ dan $\mathrm{K}$ sangat dibutuhkan untuk pertumbuhan tanaman terutama dalam merangsang pembentukan tinggi tanaman.

\section{Bobot Tongkol Tanaman Sampel} (g)

Analisis sidik ragam menunjukan bahwa perlakuan limbah ikan berpengaruh sangat nyata terhadap bobot tanaman sampel. Rata-rata bobot tanaman sampel jagung manis akibat perlakuan limbah ikan disajikan pada Tabel 5.

Tabel 5. Rata-rata bobot tongkol tanaman sampel jagung manis (g) akibat perlakuan limbah ikan

\begin{tabular}{cc}
\hline Perlakuan & Bobot Tongkol Tanaman Sampel $(\mathrm{g})$ \\
\hline $\mathrm{L}_{1}$ & $102,22 \mathrm{a}$ \\
$\mathrm{L}_{2}$ & $299,08 \mathrm{~b}$ \\
$\mathrm{~L}_{3}$ & $457,33 \mathrm{c}$ \\
$\mathrm{L}_{4}$ & $333,81 \mathrm{~b}$ \\
\hline BNJ $_{0,05}$ & 79,90 \\
\hline
\end{tabular}

Keterangan : Angka yang diikuti huruf yang sama pada kolom yang sama berbeda tidak nyata pada taraf 0,05

Tabel 7 menunjukan bahwa bobot tongkol tanaman sampel jagung manis tertinggi dijumpai pada perlakuan L3 dan terendah dijumpai pada perlakuan L1. Hasil uji $\mathrm{BNJ}_{0,05}$ perlakuan L3 berbeda nyata dengan perlakuan semua perlakuan yang lain.
Hal ini menunjukan bahwa pemberian pupuk limbah ikan mampu mencukupi kebutuhan unsur hara $\mathrm{P}$ dan $\mathrm{K}$ untuk tanaman jagung manis. Unsur hara $\mathrm{P}$ berperan dalam pembentukan bunga dan buah, sedangkan $\mathrm{K}$ berperan dalam pembentukan karbohidrat dan gula 
yang berfungsi dalam pembentukan kualitas bunga sehingga buah yang dihasilkan lebih baik.

Menurut Billalian (2016) dengan terpenuhinya kebutuhan hara maka semua proses fisiologis dalam tubuh tanaman akan berjalan dengan baik, proses pembungaan merupakan salah satu fase generatif yang merupakan metabolisme tertinggi untuk mendukung pembelahan dan pembesaran sel.

\section{Produksi per Plot (kg)}

Analisis sidik ragam menunjukan bahwa perlakuan limbah ikan berpengaruh sangat nyata terhadap produksi per plot. Rata-rata produksi per plot jagung manis akibat perlakuan limbah ikan disajikan pada Tabel 6.

Tabel 6. Rata-rata produksi per plot jagung manis (cm) akibat perlakuan limbah ikan

\begin{tabular}{cc}
\hline Perlakuan & Produksi per Plot $(\mathrm{kg})$ \\
\hline $\mathrm{L}_{1}$ & $0,70 \mathrm{a}$ \\
$\mathrm{L}_{2}$ & $2,28 \mathrm{~b}$ \\
$\mathrm{~L}_{3}$ & $4,60 \mathrm{~d}$ \\
$\mathrm{~L}_{4}$ & $2,76 \mathrm{c}$ \\
\hline BNJ $_{0,05}$ & 0,31 \\
\hline
\end{tabular}

Keterangan : Angka yang diikuti huruf yang berbeda, berbeda nyata pada taraf 0,05

Tabel 8 menunjukan bahwa produksi per plot jagung manis tertinggi dijumpai pada perlakuan $\mathrm{L}_{3}$ dan terendah dijumpai pada perlakuan $\mathrm{L}_{1}$. Hasil uji $\mathrm{BNJ}_{0,05}$ perlakuan $\mathrm{L}_{3}$ berbeda nyata dengan semua perlakuan yang lain. Hal ini diduga perlakuan $\mathrm{L}_{3}$ mampu meningkatkan jumlah mikroorganisme di dalam tanah sehingga tanah menjadi lebih subur dan memiliki pori-pori makro yang dapat mempercepat akar untuk menyerap unsur hara makro seperti $\mathrm{N}$, $\mathrm{P}$ dan $\mathrm{K}$, sehingga menghasilkan produksi yang baik.

Sesuai pendapat Margareta (2008) dalam Makiyah (2013) bahwa mikroorganisme dari hasil fermentasi dapat meningkatkan penyerapan unsur hara, karena mikroorganisme dapat meningkatkan penyerapan karbohidrat dan beberapa unsur makro seperti unsur $\mathrm{N}, \mathrm{P}$ dan $\mathrm{K}$.
Unsur $\mathrm{N}$ berfungsi untuk pertumbuhan tunas, batang dan daun, posfor (P) untuk merangsang pertumbuhan akar, buah dan biji, selanjutnya kalium (K) untuk meningkatan ketahanan tanaman terhadap serangan hama dan penyakit.

\section{Pengaruh Interaksi Tinggi Tanaman (cm)}

Hasil analisis sidik ragam rata-rata tinggi tanaman disajikan pada lampiran 2, 4 dan 6 menunjukan bahwa interaksi antara biochar dan limbah ikan berpengaruh sangat nyata terhaap tinggi tanaman jagung manis umur 15, 30 dan 45 HST.

Rata-rata tinggi tanaman jagung manis akibat perlakuan biochar dan limbah ikan disajikan pada Tabel 7. 
Tabel 7. Rata-rata tinggi tanaman jagung manis (cm) pada umur 15, 30 dan 45 HST akibat interaksi biochar dan limbah ikan

\begin{tabular}{cccc}
\hline \multirow{2}{*}{ Perlakuan } & \multicolumn{3}{c}{ Tinggi Tanaman $(\mathrm{cm})$} \\
\cline { 2 - 4 } & $15 \mathrm{HST}$ & $30 \mathrm{HST}$ & $45 \mathrm{HST}$ \\
\hline $\mathrm{B}_{1} \mathrm{~L}_{1}$ & $45,44 \mathrm{abcd}$ & $61,67 \mathrm{a}$ & $62,89 \mathrm{a}$ \\
$\mathrm{B}_{1} \mathrm{~L}_{2}$ & $46,33 \mathrm{abc}$ & $62,67 \mathrm{a}$ & $64,78 \mathrm{a}$ \\
$\mathrm{B}_{1} \mathrm{~L}_{3}$ & $53,33 \mathrm{cde}$ & $93,33 \mathrm{~b}$ & $96,00 \mathrm{c}$ \\
$\mathrm{B}_{1} \mathrm{~L}_{4}$ & $44,00 \mathrm{a}$ & $94,50 \mathrm{bc}$ & $119,78 \mathrm{~d}$ \\
$\mathrm{~B}_{2} \mathrm{~L}_{1}$ & $45,11 \mathrm{ab}$ & $89,44 \mathrm{~b}$ & $79,00 \mathrm{c}$ \\
$\mathrm{B}_{2} \mathrm{~L}_{2}$ & $45,33 \mathrm{ab}$ & $89,11 \mathrm{~b}$ & $122,67 \mathrm{~d}$ \\
$\mathrm{~B}_{2} \mathrm{~L}_{3}$ & $44,22 \mathrm{a}$ & $96,44 \mathrm{bc}$ & $194,11 \mathrm{f}$ \\
$\mathrm{B}_{2} \mathrm{~L}_{4}$ & $41,33 \mathrm{a}$ & $95,78 \mathrm{bc}$ & $205,67 \mathrm{f}$ \\
$\mathrm{B}_{3} \mathrm{~L}_{1}$ & $45,89 \mathrm{abc}$ & $90,56 \mathrm{bc}$ & $79,22 \mathrm{~b}$ \\
$\mathrm{~B}_{3} \mathrm{~L}_{2}$ & $56,11 \mathrm{cde}$ & $98.00 \mathrm{bc}$ & $256,89 \mathrm{~g}$ \\
$\mathrm{~B}_{3} \mathrm{~L}_{3}$ & $57,44 \mathrm{e}$ & $197,56 \mathrm{e}$ & $269,22 \mathrm{~g}$ \\
$\mathrm{~B}_{3} \mathrm{~L}_{4}$ & $57,78 \mathrm{e}$ & $228,67 \mathrm{e}$ & $268,89 \mathrm{~g}$ \\
$\mathrm{~B}_{4} \mathrm{~L}_{1}$ & $50,22 \mathrm{bc}$ & $104,00 \mathrm{c}$ & $163,78 \mathrm{e}$ \\
$\mathrm{B}_{4} \mathrm{~L}_{2}$ & $53,22 \mathrm{cde}$ & $138,33 \mathrm{~d}$ & $256,78 \mathrm{~g}$ \\
$\mathrm{~B}_{4} \mathrm{~L}_{3}$ & $51,22 \mathrm{cde}$ & $225,78 \mathrm{f}$ & $262,00 \mathrm{~g}$ \\
$\mathrm{~B}_{4} \mathrm{~L}_{4}$ & $53,67 \mathrm{cde}$ & $250,11 \mathrm{f}$ & $265,89 \mathrm{~g}$ \\
\hline $\mathrm{BNJ}_{0,05}$ & 11,55 & 9,89 & 12,97 \\
\hline
\end{tabular}

Keterangan : Angka yang diikuti huruf yang sama pada kolom yang sama berbeda tidak nyata pada taraf 0,05

Tabel 7 menunjukan bahwa rata-rata tinggi tanaman tertinggi pada umur 15 HST dijumpai pada perlakuan $\mathrm{B}_{3} \mathrm{~L}_{4}$ dan terendah dijumpai pada perlakuan $\mathrm{B}_{1} \mathrm{~L}_{4}$. Hasil uji $\mathrm{BNJ}_{0,05}$ menunjukan bahwa perlakuan $\mathrm{B}_{3} \mathrm{~L}_{4}$ berbeda nyata dengan perlakuan $\mathrm{B}_{1} \mathrm{~L}_{1}, \mathrm{~B}_{1} \mathrm{~L}_{2}, \mathrm{~B}_{1} \mathrm{~L}_{4}$, $\mathrm{B}_{2} \mathrm{~L}_{1}, \mathrm{~B}_{2} \mathrm{~L}_{2}, \mathrm{~B}_{2} \mathrm{~L}_{3}, \mathrm{~B}_{2} \mathrm{~L}_{4}, \mathrm{~B}_{3} \mathrm{~L}_{1}$ dan $\mathrm{B}_{4} \mathrm{~L}_{1}$, tetapi berbeda nyata dengan perlakuan yang lain.

Pada umur 30 HST menunjukan bahwa rata-rata tinggi tanaman tertinggi dijumpai pada perlakuan $\quad \mathrm{B}_{4} \mathrm{~L}_{4}$ dan terendah dijumpai pada perlakuan $\mathrm{B}_{1} \mathrm{~L}_{1}$. Hasil uji $\mathrm{BNJ}_{0,05}$ menunjukkan bahwa perlakuan $\mathrm{B}_{4} \mathrm{~L}_{4}$ tidak berbeda nyata dengan perlakuan $\mathrm{B}_{4} \mathrm{~L}_{3}$, namun berbeda nyata dengan semua perlakuan yang lain.

Pada umur 45 HST menunjukan bahwa rata-rata tinggi tanaman tertinggi dijumpai pada perlakuan $\quad \mathrm{B}_{3} \mathrm{~L}_{3} \quad$ dan terendah dijumpai pada perlakuan $\mathrm{B}_{1} \mathrm{~L}_{1}$. Hasil uji $\mathrm{BNJ}_{0,05}$ menunjukkan bahwa pada perlakuan $\mathrm{B}_{3} \mathrm{~L}_{3}$ tidak berbeda nyata dengan perlakuan $\mathrm{B}_{3} \mathrm{~L}_{2}, \mathrm{~B}_{3} \mathrm{~L}_{4}, \mathrm{~B}_{4} \mathrm{~L}_{2}$, $\mathrm{B}_{4} \mathrm{~L}_{3}$ dan $\mathrm{B}_{4} \mathrm{~L}_{4}$, namun berbeda nyata dengan perlakuan yang lain.

Hal ini diduga pada kombinasi perlakuan biochar dan limbah ikan merupakan bahan organik yang dapat menyebabkan struktur dan tekstur tanah menjadi lebih baik, meningkatkan daya ikat air, ketersedian hara menjadi lebih tersedia terutama unsur $\mathrm{N}$ yang dibutuhkan sudah terpenuhi, selain itu tanah menjadi lebih porous. Hal ini mengakibatkan tanaman dapat tumbuh optimal.

Menurut Kurniawan $d k k$ (2014) tanah dengan bahan organik yang cukup, maka aerasi berjalan dengan baik sehingga metabolisme 
tanaman dapat berlangsung dengan baik.

\section{Bobot Tongkol Tanaman Sampel} (g)

Hasil analisis sidik ragam menunjukan bahwa interaksi antara biochar dan limbah ikan berpengaruh sangat nyata terhadap bobot tongkol tanaman sampel. Ratarata bobot tanaman sampel jagung manis akibat perlakuan biochar dan limbah ikan disajikan pada Tabel 8 .
Tabel 8 menunjukan bahwa rata-rata bobot tongkol tanaman sampel jagung manis terbesar dijumpai pada perlakuan $\mathrm{B}_{3} \mathrm{~L}_{3}$ dan terendah dijumpai pada perlakuan $\mathrm{B}_{1} \mathrm{~L}_{1}$. Hasil uji $\mathrm{BNJ}_{0,05}$ menunjukan bahwa perlakuan $\mathrm{B}_{3} \mathrm{~L}_{3}$ tidak berbeda nyata dengan perlakuan $B_{3} L_{2}, B_{3} L_{4}$ dan $\mathrm{B}_{4} \mathrm{~L}_{3}$, namun berbeda nyata dengan perlakuan yang lain.

Tabel 8. Rata-rata bobot tongkol tanaman sampel jagung manis (g) akibat perlakuan biochar dan limbah ikan

\begin{tabular}{cc}
\hline Perlakuan & Bobot Tongkol Tanaman Sampel $(\mathrm{g})$ \\
\hline $\mathrm{B}_{1} \mathrm{~L}_{1}$ & $89,00 \mathrm{a}$ \\
$\mathrm{B}_{1} \mathrm{~L}_{2}$ & $160,89 \mathrm{ab}$ \\
$\mathrm{B}_{1} \mathrm{~L}_{3}$ & $367,78 \mathrm{~cd}$ \\
$\mathrm{~B}_{1} \mathrm{~L}_{4}$ & $196,67 \mathrm{ab}$ \\
$\mathrm{B}_{2} \mathrm{~L}_{1}$ & $96,44 \mathrm{a}$ \\
$\mathrm{B}_{2} \mathrm{~L}_{2}$ & $289,33 \mathrm{~cd}$ \\
$\mathrm{~B}_{2} \mathrm{~L}_{3}$ & $407,67 \mathrm{~d}$ \\
$\mathrm{~B}_{2} \mathrm{~L}_{4}$ & $372,89 \mathrm{~d}$ \\
$\mathrm{~B}_{3} \mathrm{~L}_{1}$ & $93,11 \mathrm{a}$ \\
$\mathrm{B}_{3} \mathrm{~L}_{2}$ & $535,22 \mathrm{de}$ \\
$\mathrm{B}_{3} \mathrm{~L}_{3}$ & $558,33 \mathrm{e}$ \\
$\mathrm{B}_{3} \mathrm{~L}_{4}$ & $489,67 \mathrm{de}$ \\
$\mathrm{B}_{4} \mathrm{~L}_{1}$ & $130,33 \mathrm{ab}$ \\
$\mathrm{B}_{4} \mathrm{~L}_{2}$ & $210,89 \mathrm{abc}$ \\
$\mathrm{B}_{4} \mathrm{~L}_{3}$ & $495,56 \mathrm{de}$ \\
$\mathrm{B}_{4} \mathrm{~L}_{4}$ & $276,00 \mathrm{bc}$ \\
\hline $\mathrm{BNJ}_{0,05}$ & 160,78 \\
\hline
\end{tabular}

Keterangan : Angka yang diikuti huruf yang sama berbeda tidak nyata pada taraf 0,05 
Hal ini diduga pada kombinasi perlakuan biochar dan limbah ikan merupakan kombinasi yang baik untuk meningkatkan hasil tanaman jagung manis. Biochar sekam padi sebagai pembenah tanah dapat mengurangi $\mathrm{CO}_{2}$ dari udara, didalam tanah biochar sekam padi mampu menahan air didalam tanah dan menyediakan habitat bagi mikroorganisme tanah. Sedangkan pupuk limbah ikan diketahui mampu meningkatkan unsur hara makro seperti N, P, K dan bahan organik didalam tanah yang berperan dalam pembentukan buah jagung.

Sesuai pendapat Gani (2009) Biochar mampu menahan dan menjadikan air dan nutrisi lebih tersedia bagi tanaman, jika digunakan bersama pupuk organik biochar sekam padi dapat meningkatkan produktivitas serta ketersediaan hara bagi tanaman.

\section{Produksi per Plot (kg)}

$\begin{array}{clr}\text { Hasil } & \text { analisis sidik } & \text { ragam } \\ \text { rata-rata } & \text { produksi } & \text { perplot }\end{array}$ menunjukan bahwa interaksi antara biochar dan limbah ikan berpengaruh sangat nyata terhadap produksi per plot. Rata-rata produksi per plot jagung manis akibat perlakuan biochar dan limbah ikan disajikan pada Tabel 9.

Tabel 9. Rata-rata produksi per plot jagung manis $(\mathrm{kg})$ akibat perlakuan biochar dan limbah ikan

\begin{tabular}{cc}
\hline Perlakuan & Produksi per Plot $(\mathrm{kg})$ \\
\hline $\mathrm{B}_{1} \mathrm{~L}_{1}$ & $0,53 \mathrm{a}$ \\
$\mathrm{B}_{1} \mathrm{~L}_{2}$ & $0,57 \mathrm{a}$ \\
$\mathrm{B}_{1} \mathrm{~L}_{3}$ & $2,78 \mathrm{~cd}$ \\
$\mathrm{~B}_{1} \mathrm{~L}_{4}$ & $0,57 \mathrm{a}$ \\
$\mathrm{B}_{2} \mathrm{~L}_{1}$ & $0,77 \mathrm{ab}$ \\
$\mathrm{B}_{2} \mathrm{~L}_{2}$ & $1,35 \mathrm{~b}$ \\
$\mathrm{~B}_{2} \mathrm{~L}_{3}$ & $5,20 \mathrm{e}$ \\
$\mathrm{B}_{2} \mathrm{~L}_{4}$ & $2,31 \mathrm{c}$ \\
$\mathrm{B}_{3} \mathrm{~L}_{1}$ & $0,72 \mathrm{a}$ \\
$\mathrm{B}_{3} \mathrm{~L}_{2}$ & $4,60 \mathrm{e}$ \\
$\mathrm{B}_{3} \mathrm{~L}_{3}$ & $5,16 \mathrm{e}$ \\
$\mathrm{B}_{3} \mathrm{~L}_{4}$ & $4,59 \mathrm{e}$ \\
$\mathrm{B}_{4} \mathrm{~L}_{1}$ & $0,80 \mathrm{ab}$ \\
$\mathrm{B}_{4} \mathrm{~L}_{2}$ & $2,62 \mathrm{c}$ \\
$\mathrm{B}_{4} \mathrm{~L}_{3}$ & $5,26 \mathrm{e}$ \\
$\mathrm{B}_{4} \mathrm{~L}_{4}$ & $3,58 \mathrm{~d}$ \\
\hline $\mathrm{BNJ}_{0,05}$ & 0,62 \\
\hline
\end{tabular}

Keterangan : Angka yang diikuti huruf yang sama berbeda tidak nyata pada taraf 0,05 
Tabel 9 menunjukan bahwa rata-rata produksi per plot jagung manis terberat dijumpai pada perlakuan $\mathrm{B}_{4} \mathrm{~L}_{3}$ dan terendah dijumpai pada perlakuan $\mathrm{B}_{1} \mathrm{~L}_{1}$. Hasil uji $\mathrm{BNJ}_{0,05}$ menunjukan bahwa perlakuan $\mathrm{B}_{4} \mathrm{~L}_{3}$ tidak berbeda nyata dengan perlakuan $\mathrm{B}_{2} \mathrm{~L}_{3}, \mathrm{~B}_{3} \mathrm{~L}_{2}, \mathrm{~B}_{3} \mathrm{~L}_{3}$ dan $\mathrm{B}_{3} \mathrm{~L}_{4}$, namun berbeda nyata dengan perlakuan yang lain.

Hal ini diduga biochar dan limbah ikan merupakan kombinasi yang tepat untuk meningkatkan produksi tanaman jagung manis, hal tersebut karena biochar sekam padi dapat meningkatkan daya serap terhadap air. Sehingga kelembaban pada akar tanaman akan terjaga dengan baik, sedangkan limbah ikan sebagai pembenah tanah dan membantu meningkatkan unsur hara nitrogen, fospor dan kalium. Selain itu berfungsi untuk menggemburkan tanah sehingga mempermudah akar tanaman menyerap unsur hara didalam tanah.

Sesuai dengan pendapat Hakim $d k k$ (1986), bahwa tanah harus cukup mengandung air dan udara serta cukup gembur agar dapat tumbuh dengan baik dan menyerap unsur hara yang cukup bagi pertumbuhannya.

\section{SIMPULAN DAN SARAN}

\section{Simpulan}

1. Perlakuan biochar berpengaruh sangat nyata terhadap tinggi tanaman pada umur 30 dan 45 HST, bobot tongkol tanaman sampel dan produksi per plot. Perlakuan terbaik dijumpai pada perlakuan $\mathrm{B}_{4}$ (biochar 7,5 ton/ha).

2. Perlakuan limbah ikan berpengaruh sangat nyata terhadap tinggi tanaman pada umur 30 dan 45 HST, bobot tongkol tanaman sampel, produksi per plot. Perlakuan terbaik dijumpai pada perlakuan $\mathrm{L}_{4}$ (Limbah ikan $150 \mathrm{ml} /$ liter air).

3. Interaksi biochar dan limbah ikan berpengaruh sangat nyata terhadap tinggi tanaman 15,30 dan 45 HST, bobot tanaman sampel dan produksi perplot. Kombinasi perlakuan terbaik dijumpai pada $\mathrm{B}_{4} \mathrm{~L}_{4}$ (biochar 7,5 ton/ha dan limbah ikan 150 $\mathrm{ml} /$ liter air)

\section{Saran}

1. Untuk mendapatkan pertumbuhan dan produksi tanaman jagung manis yang baik disarankan menggunakan biochar 7,5 ton/ha dan limbah ikan $150 \mathrm{ml} /$ liter air.

2. Diperlukan penelitian lanjutan dengan perlakuan biochar dan limbah ikan yang lebih bervariasi.

\section{DAFTAR PUSTAKA}

Billalian, H.I., Rahayu, Y., Brasmasto, Y. 2016. Pemanfaatan Limbah Cair Tahu Sebagai Penambah Nutrisi Pertumbuhan Bibit Sengon

(Falcatarimoluccana). Balai Penelitian Pengembangan Teknologi Perbanihan Tanaman Hutan Bogor.

Dariah, A,. Nurida, N. L. 2012. Pemanfaatan Biochar Untuk Meningkatkan Produktivitas Lahan Kering Beriklim Kering. Badan Litbang Pertanian. Bogor.

Gani, A. 2009 Biochar Penyelamat Lingkungan.

Warta Penelitian dan Pengembangan Pertanian, 31(6) : 1-6. 
Hanafiah, K.A. 2013. Dasar-dasar Ilmu Tanah. Raja Grafindo Persada. Jakarta. 2014. Rancangan Percobaan (Teori dan Aplikasi). Raja Grafindo Persada.Jakarta.

Hakim, dkk. 1986. Dasar-dasarIlmu Tanah. Universitas Lampung. Lampung.

Hadisuwito, S. 2007. Membuat Pupuk Kompos Cair. Jakarta Agromedia Pustaka.

Kurniawan., Bintaro., Riniarti. 2014. Pengaruh Beberapa Dosis Pupuk dan Beberapa Media Tumbuh terhadap Pertumbuhan Bibit Jabon (Anthocepholus cadamba). Jurusan Kehutanan. Fakultas Pertanian, Universitas

Lampung. Lampung.

Komarayati, dkk. 2012. Arang dan Cuka Kayu Produksi Hasil Hutan Bukan Kayu Untuk Meningkatkan Pertumbuhan Tanamandan Serapan Hara Karbon. Pusat Penelitian dan Pengembangan Keteknikan Kehutanan dan Pengelolaan Hasil Hutan. Jl. Gunung Batu No. 5, Bogor.

Makiyah, M. 2013. Analisa Kadar N, $P$ dan K pada Pupuk Cair Limbah Tahu degan Penanaman Tanaman Matahari Meksiko (Thritonia diversivolia). Skripsi. Jurusan Kimia. Fakultas Matematika dan Ilmu Pengetahuan Alam. Universitas Negeri Semarang.

Mursalim, I. 2018 Pengaruh Penggunaan Pupuk Organik Mikroorganisme Lokal Media
Nasi, Batang Pisang, dan Ikan Tongkol terhadap Pertumbuhan Tanaman Sawi (Brassica Juncea). Skripsi. Fakultas Tarbiyah dan Keguruan. UIN Alaluddin Makasar.

Maguire, R. O., Agblevor, F.A. 2010. Biochar dalam Sistem Pertanian. Perguruan Tinggi Pertanian dan Ilmu Kehidupan, Virginia Polytechnic Institute.

Prahasta, A. 2009. Agribisnis Jagung. Pustaka Grafika. Bandung.

Prasetya, B., Kurniawan, S., Febrianingsih. 2009. Pengaruh Dosis dan Frekuensi Pupuk Cair terhadap Serapan dan Pertumbuhan Sawi (Brassica junsea L.) pada Entisol. Universitas Brawijaya. Malang

Syukur, M., Azis, R. 2014. Jagung Manis. Penebar Swadaya. Jakarta.

Satriawan, B.D., Handayanto, E. 2015. Pengaruh Aplikasi Biochar dan Residu Tanaman Terhadap Sifat Kimia dari Tanah Terdegradasi Malang Selatan, dan $P$ Serap oleh Jagung. Jurnal Lands Terdegradasi dan Mining, 2 (2): $271-281$.

Warnock, D.D., Lehmann, J., Kuyper, T.W., Riling, M.C. 2007. Mycorrhizal Responses to Biochar in soil-Concepts and Mechanisms. J. Plant and Soil. 